\title{
Pakistan's Response to COVID-19: Overcoming National and International Hypes to Fight the Pandemic
}

Hashaam Akhtar ${ }^{1}$, PhD; Maham Afridi ${ }^{2}$, MPhil; Samar Akhtar ${ }^{1}$, PhD; Hamaad Ahmad ${ }^{1}$, MPhil; Sabahat Ali ${ }^{3}$, MBBS; Sundas Khalid ${ }^{4}$, MSc; Sajid Mahmood Awan ${ }^{1}$, DPharm; Shahzaib Jahangiri ${ }^{1}$, DPharm; Yousef Saleh Khader ${ }^{5}$, PhD

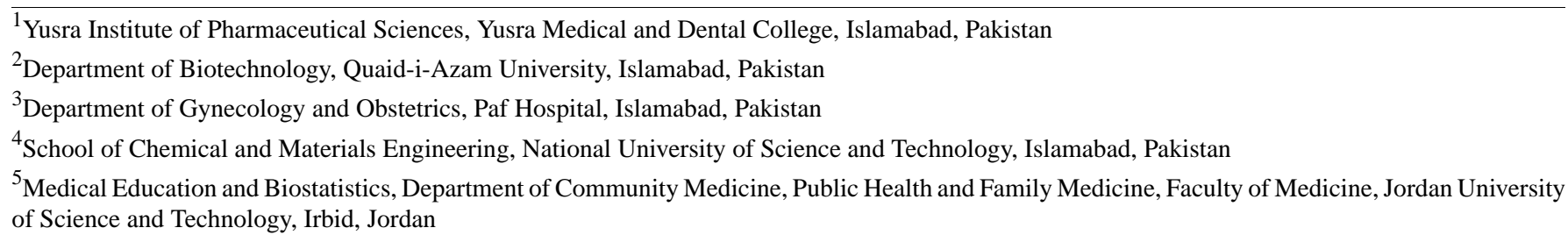

Corresponding Author:

Hashaam Akhtar, PhD

Yusra Institute of Pharmaceutical Sciences

Yusra Medical and Dental College

Zaraj Housing Society, Opposite DHA Phase 2 Gate III, Main GT Road

Islamabad, 44000

Pakistan

Phone: 923165163945

Email: hashaamakhtar@gmail.com

\begin{abstract}
The COVID-19 outbreak started as pneumonia in December 2019 in Wuhan, China. The subsequent pandemic was declared as the sixth public health emergency of international concern on January 30, 2020, by the World Health Organization. Pakistan could be a potential hotspot for COVID-19 owing to its high population of 204.65 million and its struggling health care and economic systems. Pakistan was able to tackle the challenge with relatively mild repercussions. The present analysis has been conducted to highlight the situation of the disease in Pakistan in 2020 and the measures taken by various stakeholders coupled with support from the community to abate the risk of catastrophic spread of the virus.
\end{abstract}

(JMIR Public Health Surveill 2021;7(5):e28517) doi: 10.2196/28517

\section{KEYWORDS}

community health; coronavirus; COVID-19; epidemic; epidemiology; Pakistan; pandemic; public health emergency of international concern

\section{Introduction}

COVID-19 started as an outbreak of a series of unusual pneumonia cases in Wuhan, China, with the earliest cases reported to the World Health Organization's country office in China on December 31, 2019. By January 12, 2020, the causative agent was identified as a novel coronavirus, initially termed "2019-nCoV," and up to 41 cases had been preliminarily diagnosed [1,2]. The virus has since been renamed as SARS-CoV-2 and spread drastically, and COVID-19 was declared as pandemic by the World Health Organization (WHO) on March 11, 2020 [3]. Having currently affected more than 210 countries and territories, with 19,550,650 active cases and a mortality rate of $2.85 \%$ as of December 31,2020 , the
COVID-19 pandemic continues to be a major global public health concern [4].

\section{Pakistan: Epidemiologic Profile}

COVID-19 cases were reported from Islamabad and Karachi on February 26, 2020 [5]. Pakistan being one of the most densely populated countries in Asia, with a population of 204.65 million, and Karachi being the largest metropolitan city in Pakistan, has been greatly vulnerable to this outbreak [6]. Owing to its present economic condition, health care resources, and the occurrence of previous outbreaks, the Centers for Disease Control and Prevention had already issued a level 3 warning for international travelers to Pakistan [7]. The administration had a huge responsibility to constrain the spread through a timely response 
and the adoption of appropriate measures to avoid any major catastrophe. The disease was initially difficult to contain, especially because of noncompliance of the general population to the necessary measures and timely reporting of symptoms. Within 45 days, on April 10, 2020, Pakistan reported 4601 confirmed cases with a death toll approaching 66 individuals [8].

\section{Public and Community Response to the COVID-19 Pandemic}

There was a mixed response from the community. Few people paid attention to the news and some even considered it fake. News of the virus being a hoax or propaganda spread greatly worldwide and countered the efforts of governments and other agencies that made marked efforts to tackle the spread of the pandemic $[9,10]$. Common rumors on COVID-19 emergence and treatment through the media and social media resources are presented in Table 1.

Table 1. Rumors related to COVID-19 emergence and treatment.

Rumors
The virus is no worse than the one that causes common cold
Hand dryers are effective in eliminating the coronavirus
Coronavirus originated with people eating bats in China
There is a vaccine or cure for coronavirus, which the government will not
release
Coronavirus will disappear by the summer
Vitamin C can help you ward off coronavirus
A "miracle" bleach product can cure coronavirus
Dean Koontz predicted the coronavirus in his 1981 novel The Eyes of
Darkness
Osaka flu shown in the television show The Simpsons
If you cannot hold your breath for 10 seconds without coughing, then you
have coronavirus
The country will be placed in a nationwide quarantine effective immedi-
ately
Government'S Initiatives to Tackle the
Pandemic

The government of Pakistan has been lauded by international organizations including the WHO (and rightly so) for taking the necessary precautions and measures against the COVID-19 pandemic to guarantee not only the containment of disease spread but also to fulfill its responsibility as a state toward its people and their safety [14].

\section{Immediate Response to Contain Disease Spread}

One of the first steps taken by the government was to develop functional emergency operations centers and to detect the route of disease spread in Pakistan. The origin of the virus was the first question; hence, detailed history-taking of patients was crucial not only in understanding the outbreak but also in determining the contacts of patients with other people in the community [15]. This helped in cordoning off areas or home-bounding people who came in close contact with a patient with COVID-19. In addition to this, patients with a recent international travel history were monitored closely. This made sense because many cases and massive spread was reported in the countries neighboring Pakistan [15-17].

\section{Source}

WHO's COVID-19 advice for the public: Mythbusters [9]

Chinese social media pages $[9,10]$

YouTube videos, conservative tabloids, blogs, and Twitter $[9,10]$

Facebook post containing a screenshot of a patent CO-V vaccine by the Centers for Disease Control and Prevention on January 22, 2020 [9,10]

WHO's COVID-19 advice for the public: Mythbusters [9,11]

A popular social media post [12]

Far-right conspiracy theory QAnon misinforming people to drink Miracle Mineral Solution, a bleach-based product [13]

Dean Koontz's 1981 novel The Eyes of Darkness became very popular on Twitter [10]

Screenshots allegedly from the "Marge in Chains" episode in 1993 on social media [10]

Self-check coronavirus tests on social media originating in March 2020 [10]

Text messages claiming the implementation of a country-wide lockdown [10]

\section{Containment Measures}

Once primary and secondary contact-tracing was delineated, the foremost step taken by the government was to control the borders [18]. This was a crucial decision, owing to the consideration of a large number of Pakistani students and pilgrims studying in and travelling from China, Iran, and Europe. The government gained the confidence of the affected individuals and their families. It was almost unfeasible to restrict such individuals outside the country because of the strong public response; nonetheless, it was necessary if the spread of the virus was to be controlled quickly. To tackle this problem, the government took the initiative of designating quarantine houses near borders and airports to isolate people entering Pakistan for a short period to make sure they were not infected before they moved out in the community [19,20].

\section{Border Control}

The WHO reported that the number of new cases increased by the minute, and disease spread was now not only limited to people who had a recent travel history in the regions highly affected by the pandemic. Disease spread within the community was alarming and called for drastic steps to be taken not only by local governments but also by countries and states at large. 
All necessary services and measures are still being used in maximum capacity till date to ensure the safety of people's lives in the country. Since all cases initially had a history of recent travel, it was speculated that transmissions were imported from outside of the country. Therefore, travel restrictions were imposed to limit the spread of virus from other countries to Pakistan [21].

\section{Quarantine Houses}

After the borders were contained, it was important for the government to provide a solution to all individuals stuck at the borders to enter the country without imposing a threat to the rest of the community [20]. It was crucial to quarantine the people at a specific location and either have them tested or wait for at least 2 weeks to ensure that they were not infected with SARS-CoV-2 before they travelled to their hometowns. People who did not show any symptoms after being quarantined for a certain duration could go to their cities and notify the authorities in case of any signs and symptoms after leaving the quarantine homes [19,20]. The development of these shelters was an economically and strategically massive task for the government. More than 3000 pilgrims arrived from Iran in the first week of March 2020 alone and were housed at quarantine shelters in Taftan and Chaman [22,23].

Toward the end of March 2020, the government decided to relocate the pilgrims to their respective provinces where quarantine centers were set up. Most news outlets and social media users condemned this step taken by the government. Many problems were faced by the pilgrims and other people who were quarantined at these centers, including included small, cramped spaces for people to live in, unhygienic conditions, shortage of food, water, medication, and unavailability of physicians [23].

\section{Country-Wide Lockdown}

Many other steps were taken by the government to tackle disease spread and to minimize the damage caused by the pandemic in Pakistan [24,25].

One of the first steps that the government of Pakistan took to limit the spread of the virus within the community was to impose well-planned lockdowns in all major cities [20,26]. Lockdowns were imposed during different hours in different regions, and most of the public spaces were closed off except for grocery stores, pharmacies, and vegetable and fruit shops. All the eateries, parks, wedding halls, schools, and offices were closed until further notice by the federal government [27]. This led to retaliation from the provincial governments and opposition as it posed a great economic threat to the country's daily-wage workers and to the low-income population; however, this was a necessary measure to curtail disease spread. Another step that the government took, and faced major opposition, was the closure of prayers at mosques, including Friday prayers $[26,28,29]$.

\section{Cordoning Off Areas}

When reports of virus transmission started emerging, especially in the federal capital of Islamabad, the government took the initiative of sealing off areas that reported infections. According to a notification issued by the District Magistrate Islamabad, the city administration decided to cordon off areas to ensure public safety after the number of infections increased [30]. Samples were tested by the National Institute of Health, Islamabad, and analyzed by epidemiologists of the deputy commissioner of the COVID-19 Nerve Centre after which the notification was issued. This helped in not only curbing the spread of the infection but also in contact-tracing and further testing of the public.

\section{Testing and Contact Tracing}

The country's testing capacity was limited during the early months of the pandemic, and while high-income countries were conducting large-scale randomized tests to estimate the actual number of confirmed cases, Pakistan was forced to carry out priority-based testing and rely on the enforcement of strict quarantine and isolation strategies to contain the pandemic [31]. Contact-tracing, however, was an effective strategy that not only helped limit the spread of the virus but also helped predict its route through different regions of the country and across different age groups. Nevertheless, since large-scale testing was crucial to assess the severity of the pandemic, the testing capacity of laboratories and the availability of testing kits was gradually increased by the government, and in June 2020 up to 30,000 tests were conducted daily to ascertain the pace of spread and to formulate future strategies accordingly [32]. Both these strategies provided valuable insights on the differences in the clinical manifestation of COVID-19 in people with different demographic and health backgrounds.

\section{Field Epidemiology Laboratory Training Program}

The Training Programs in Epidemiology and Public Health Interventions Network is a network of 75 field epidemiology training programs, which operate in $>100$ countries including Pakistan. After the WHO declared COVID-19 a public health emergency of international concern, alumni from the Field Epidemiology Training Program implemented standard operating procedures (SOPs) for COVID-19 screening at international airports in Pakistan. They also designed and implemented a real-time data entry system to screen travelers from high-risk countries [33].

\section{Implementation of SOPs: Masks, Sanitization, and Social Distancing}

SOPs were devised for the public and were meant to be strictly followed in public areas. These included guidelines on social distancing; that is, avoiding crowded areas, maintaining a physical distance of 3 feet, wearing masks, maintaining hand hygiene, sanitizing frequently touched surfaces and areas, and following general hygiene rules such as avoiding touching the face, nose, or eyes, and coughing, or sneezing in the elbow or a paper napkin instead of the hands. The authorities started taking disciplinary action against those who violated the SOPs at public places in various parts of the country in accordance with the recommendations of the National Command and Control Centre of Pakistan. The focus of the National Command and Control Centre was on SOPs, compliance, strict administrative actions being implemented, and enforcement of various strands of the track, trace, and quarantine strategy [34]. 


\section{Initiation of Awareness Campaigns: Role of Community Health workers}

Many campaigns were initiated by both local and federal governments in the interest of the general population to spread awareness about the risks, signs, and symptoms of COVID-19 [35]. Pakistan's extensive polio vaccination program, consisting of more than 265,000 community health workers and vaccinators, was mobilized with the help of the WHO [36]. This not only helped provide infrastructure to track and trace cases early during the epidemic but also helped spread awareness in the remote, underdeveloped rural regions of Pakistan. Another vital step was taken to spread awareness to the masses, where text messages were sent by the government of Pakistan on all mobile networks [37]. The daily reminders on following SOPs helped tackle those who did not take the necessary precautions and were unaware of the aforementioned information, and the imposition of fines and charges for noncompliance made risk and awareness campaigns a nationwide success [35,37].

Recorded voice messages in various local languages including Urdu, Pashto, and Sindhi, which warned against the risks of COVID-19, its spread, and its complications, and general awareness regarding the SOPs to help control its spread, were used as caller tunes before every phone call. The recorded messages were changed in accordance with the situation and ranged from guidelines on SOPs, warning noncompliers, and even congratulating efforts after successfully controlling disease spread during August 2020 [37].

\section{Economic Measures}

On the emergence of COVID-19 in Pakistan, the entire system faced various problems owing to the limitations of the health care system, poor infrastructure, uneven access to health care, resistance from various social, political, cultural, and religious groups, political instability, economic fragilities, and mistrust among the public. Data of a web-based survey conducted by the Small and Medium Enterprises Development Authority from April 3-14, 2020, among 920 businesses revealed insufficient revenue generation, losses, and difficulty in survival among businesses [38]. Pakistan launched various schemes to tackle the economic crisis faced by many individuals during the pandemic. On May 2, 2020, Prime Minister Imran Khan launched a relief scheme for people who lost their jobs or whose source of income has been compromised owing to the lockdown. He launched a cash assistance program through the Ehsaas Cash Programme to support unemployed individuals [39].

After lifting the lockdown in some sectors, the government allowed construction and daily-wage workers to resume working while dutifully following the SOPs and taking necessary precautions. This helped ease some of the economic burdens of the government, especially in providing rations and relief packages for the daily-wage workers [40].

Furthermore, the government also requested people who had been diagnosed with mild or asymptomatic COVID-19 to quarantine at home as some of them did not required hospital care; this helped curb the patient influx in hospitals and at diagnostic centers, thus easing the burden on health workers and medical practitioners [41].

\section{Production of Ventilators}

One of the largest concerns for the ministry of health and health departments in Pakistan and worldwide is coping with the continuously increasing demand of ventilators as the virus spreads and the number of cases increases. The shortage of ventilators is a major issue faced by Pakistan, especially because all the major medical equipment are imported and not produced locally. To tackle this problem, the National Radio and Telecommunication Corporation produced its first ventilator locally within a few months of the onset of the pandemic [42]. The National Radio and Telecommunications Corporation initially offered cost-free repairs for almost 109 ventilators throughout the country and later designed and produced its own ventilators. Initially, 8 ventilators were produced and handed over to the National Disaster Management Authority after which the prime minister formally inaugurated a facility for large-scale production of ventilators within Pakistan [43].

As a result of all the efforts made by the government of Pakistan, 6 months after reporting its first case, active cases in Pakistan are continuing to steadily decrease, with the number of deaths recorded in a day now often down to single-digit numbers. The country has had 312,263 confirmed cases of as on October 1 , 2020, with 6479 COVID-19-related deaths, according to the official data [44]. Save for single-day glitches, active cases have been progressively declining since peaking in June 2020, currently standing at 8903 , their lowest level since late April 2020 .

\section{Success Stories: Pakistan's Population Coming Together to Combat COVID-19}

Pakistan is currently faced with one of its toughest challenges since its establishment as an independent nation, and while COVID-19 has severely disrupted routines and led to intense fear among the public, efforts are still being made to bring together the expertise and knowledge of individuals from various fields to ensure combating this pandemic together. In addition to the government's efforts, many other organizations and individuals came forward to help against the pandemic in various capacities. From using social media to campaign for blood donations for patients with thalassemia nationwide to arranging food supplies and relief packages for those severely affected by the pandemic, the local people of Pakistan came forward and helped fellow citizens.

The Human Development Foundation Pakistan is one of the oldest nonprofit organizations in the country, and it estimated the provision and distribution of more than 14,000 ration packages containing food and medical supplies to the people of Karachi [45].

\section{Al-Khidmat Foundation Pakistan}

Al-Khidmat Foundation Pakistan is one of the leading nonprofit foundations operating in Pakistan for the past 30 years. During the onset of the pandemic, it played a vital role in charity work including awareness campaigns, providing preventive equipment such as soap, sanitizers, masks, and relevant reading material to the general public, providing its services to government institutions including hospitals, Aghosh homes, ambulances, 
and trained volunteers. Moreover, it carried out food drives, provided COVID-19 test facilities and antibody tests, and arranged for protective equipment to distribute among physicians and medical staff on the frontline [46]. Al-Khidmat Foundation Pakistan also played a vital role in arranging free plasma for patients with COVID-19 [47].

\section{Corona Recovered Warriors}

The Facebook page titled "Corona Recovered Warriors" provided hope during the grim period of disease spread in Pakistan. Created by musician Zoraiz Riaz with the aim to help coordinate convalescent plasma donations for people with COVID-19 in Pakistan, this group quickly gained popularity and had 320,000 members in just 1 month, needing a team of 33 volunteers to manage the posts. People looking for plasma donors, medical supplies, oxygen cylinders, ventilators, injection drugs or other drugs, and leads on hospitals accepting new admittees posted all their queries on this group, and thousands of people came forward and offered help in all capacities to those in need [48]. The group then started organizing donation and food drives, providing personal protective equipment (PPE) to health care workers and delivering medical supplies to desperate families of patients with COVID-19 [49].

\section{Plasma Trials by Medical Professionals}

In desperate times when everyone is seeking any cure to tackle the virus, many unapproved and untested remedies were used even by health care professionals to treat individuals with COVID-19. The most popular one was the use of plasma of a recovered patient to treat patients with COVID-19. Dr Shahid Junejo, a senior superintendent at a civil hospital, tested plasma therapy on a patient in Hyderabad. According to him, the decision for the trial was taken after consultation with the vice chancellor of the Liaquat University of Medical and Health Sciences Jamshoro, Prof Bikha Ram Devrajani [50]. Passive immunization is an old procedure used in the absence of a vaccine to treat infectious diseases; hence, the treatment was administered to many patients throughout the country without any strong evidence of its ability to neutralize the virus [51]. Even though the Ministry of National Health Services declared that plasma therapy is not a cure for COVID-19 as it is still undergoing a clinical trial on a global scale, there is still a high demand of plasma donors, and as of July 2020 approximately 750 donors were connected with critical patients through the Corona Recovered Warriors Facebook page alone.

\section{Availability of Scholars Against COVID-19 Pakistan}

Scholars Against COVID-19 is a platform of over 3000 young scholars and researchers nationwide coming together as volunteers to assist the government and people through donations of equipment from laboratories and universities to scale up testing and experimentation related to the diagnosis and treatment of COVID-19 [52]. Their aim is to bridge the disconnect among various sectors in Pakistan, which makes executing such ideas challenging.

\section{Student Taskforce Against COVID-19}

Student Taskforce Against COVID-19 is a group of final-year medical students from Aga Khan University Hospital who conceived the idea of creating a helpline for families and patients affected by COVID-19 who have been looking for guidelines and help [53]. The taskforce is not only managing the helpline but also assisting the Aga Khan University Hospital and the Sindh government in contact-tracing and helping the Pakistan Medical Association in identifying and providing volunteers to help at Karachi's Expo Centre isolation ward for patients with COVID-19 [54].

\section{First Response Initiative of Pakistan}

Over 400 medical students have come together through the Combat Corona campaign and are aiming to collect and provide PPE to health care workers. They have targeted hospitals in Karachi needing PPE and have collected hundreds of equipment for distribution through donations in all major hospitals of the city [54].

\section{Pakistan Against COVID-19 Volunteers Group}

Pakistan Against COVID-19 Volunteers is a group of physicians and other professionals who have collaborated and aim to enable connections between manufacturers and suppliers of PPE, carry out innovation and experimentation for designing and manufacturing ventilators through 3D printing technology, and develop noncontact thermometers locally $[55,56]$.

\section{Kwickdoctor.com}

Kwickdoctor.com has been developed by 40-year-old information technology expert Salman Khan. He aims to connect the public to consultants, physicians, pharmacies, and laboratories and even delivers prescriptions at the doorstep. With the pandemic spreading, the need to avoid contact has increased and digital care is the need of the hour [57].

\section{Discussion}

\section{Principal Findings}

COVID-19, after being first reported in December 2019, is still swiftly spreading worldwide. Within 10 months, the mortality and morbidity rates have approached unexpected levels. Scientists, researchers, and clinicians have worked together with engineers to develop treatments, diagnostic kits, and vaccines to prevent this infection from spreading further; however, a third wave of COVID-19 is currently underway worldwide with numerous mutant strains. These mutations have rendered this virus either more virulent or resistant to previously used medications [58]. The second wave has been feared as the situation was reverting to normalcy and businesses, offices, and schools were reopening in late September or early October of 2020. The government of Pakistan started tackling COVID-19 on the basis of the experience of other countries as the disease approached Pakistan after having affected many other countries. Starting from preparing special wards, using all resources including polio and dengue teams and wards, respectively, preparing appropriate SOPs, conveying awareness messages to everyone through the television or mobile phones, updating everyone through special mobile apps and websites, showing hotspots, sharing the economic burden with the weak, and ending with smart lockdowns were some of the most impressive measures to handle the pandemic. The people of Pakistan also supported the government during this time, which is one of the 
most prominent reasons Pakistan overcame the first 2 waves with minimal morbidities compared to other countries.

\section{Conclusions}

Immunization and treatment of COVID-19 may still be questionable, but precautions and SOPs have undoubtedly been set by many. Technology has played its part in spreading awareness, but Pakistan is currently undergoing a third wave of infections. However, if precautions are taken and all SOPs are followed, the entire community can be rescued and the risk of reinfection and further waves would decline immediately. This is a situation where everyone has a responsibility toward the community and must take steps to minimize the risk of further disease spread. Pakistan has shown tremendous potential in public health, and different government and nongovernment organizations can collaborate to address the challenges through the engagement of society and the community along with the introduction of new policies.

\section{Conflicts of Interest}

None declared.

\section{References}

1. Novel Coronavirus - China. World Health Organization. 2020 Jan 12. URL: https://www.who.int/csr/don/ 12-january-2020-novel-coronavirus-china/en/ [accessed 2021-05-04]

2. Hui DS, I Azhar E, Madani TA, Ntoumi F, Kock R, Dar O, et al. The continuing 2019-nCoV epidemic threat of novel coronaviruses to global health - The latest 2019 novel coronavirus outbreak in Wuhan, China. Int J Infect Dis 2020 Feb;91:264-266 [FREE Full text] [doi: 10.1016/j.ijid.2020.01.009] [Medline: 31953166]

3. Cucinotta D, Vanelli M. WHO Declares COVID-19 a Pandemic. Acta Biomed 2020 Mar 19;91(1):157-160 [FREE Full text] [doi: 10.23750/abm.v91i1.9397] [Medline: $\underline{32191675]}$

4. Coronavirus Worldwide Graphs. Worldometer. URL: https://www.worldometers.info/coronavirus/worldwide-graphs/ [accessed 2020-12-31]

5. Pakistan Statistical Year Book 2018 (Provisional). Pakistan Bureau of Statistics: Government of Pakistan. URL: https:/ /www.pbs.gov.pk/sites/default/files//PAKISTAN\%20STATISTICAL\%20YEAR\%20BOOK\%202018.pdf [accessed 2020-03-16]

6. Abid K, Bari YA, Younas M, Tahir Javaid S, Imran A. Progress of COVID-19 Epidemic in Pakistan. Asia Pac J Public Health 2020 May;32(4):154-156 [FREE Full text] [doi: 10.1177/1010539520927259] [Medline: 32429679]

7. COVID-19 in Pakistan. Centers for Disease Control and Prevention. URL: https://wwwnc.cdc.gov/travel/notices/warning/ coronavirus-pakistan [accessed 2020-09-29]

8. See the Realtime Pakistan and Worldwide COVID-19 Situation!. Government of Pakistan. URL: http://covid.gov.pk/ [accessed 2020-04-06]

9. Coronavirus disease (COVID-19) advice for the public: Mythbusters. World Health Organization. URL: https://www. who.int/emergencies/diseases/novel-coronavirus-2019/advice-for-public/myth-busters [accessed 2020-03-16]

10. Dickson EJ. Coronavirus Is Spreading — And So Are the Hoaxes and Conspiracy Theories Around It. Rolling Stone. 2020 Mar 18. URL: https://www.rollingstone.com/culture/culture-news/coronavirus-china-bat-patent-conspiracy-theory-942416/ [accessed 2020-03-27]

11. 40 times Trump said the coronavirus would go away. The Washington Post. 2020 Nov 02. URL: https://www. washingtonpost.com/video/politics/40-times-trump-said-the-coronavirus-would-go-away/2020/04/30/ d2593312-9593-4ec2-aff7-72c1438fca0e video.html [accessed 2020-09-16]

12. Matt B. Fact Check: Could taking Vitamin C cure or prevent COVID-19. USA Today. 2020 Mar 24. URL: https://www. usatoday.com/story/news/factcheck/2020/03/24/coronavirus-fact-check-could-vitamin-c-cure-covid-19/2904303001/ [accessed 2020-03-27]

13. Broderick R. QAnon Supporters And Anti-Vaxxers Are Spreading A Hoax That Bill Gates Created The Coronavirus. BuzzFeed News. 2020 Jan 23. URL: http://www.buzzfeednews.com/articles/ryanhatesthis/ qanon-supporters-and-anti-vaxxers-are-spreading-a-hoax [accessed 2020-09-16]

14. Gul A. Pakistan Lifts Lockdowns, Top UN Diplomat Lauds Anti-Virus Gains. Voice of America. 2020 Aug 10. URL: https://www.voanews.com/south-central-asia/pakistan-lifts-lockdowns-top-un-diplomat-lauds-anti-virus-gains [accessed 2020-09-28]

15. Corona patients with travel history to be allocated tag numbers. The Express Tribune. 2020 Apr 19. URL: https://tribune. com.pk/story/2201833/corona-patients-travel-history-allocated-tag-numbers [accessed 2020-09-28]

16. Badshah SL, Ullah A, Badshah SH, Ahmad I. Spread of Novel coronavirus by returning pilgrims from Iran to Pakistan. J Travel Med 2020 May 18;27(3):taaa044 [FREE Full text] [doi: 10.1093/jtm/taaa044] [Medline: $\underline{32268358]}$

17. Pakistan on alert over deadly China virus. The Express Tribune. 2020 Jan 22. URL: https://tribune.com.pk/story/2142464/ pakistan-alert-deadly-china-virus [accessed 2020-10-04]

18. Pakistan Travel Advisory. US Department of State - Bureau of Consular Affairs. URL: https://travel.state.gov/content/ travel/en/traveladvisories/traveladvisories/pakistan-travel-advisory.html [accessed 2020-10-04] 
19. Abid K, Bari YA, Younas M, Tahir Javaid S, Imran A. Progress of COVID-19 Epidemic in Pakistan. Asia Pac J Public Health 2020 May;32(4):154-156 [FREE Full text] [doi: 10.1177/1010539520927259] [Medline: $\underline{32429679]}$

20. Ahmad T. Pakistan: "Smart Lockdown" Imposed across Cities of Pakistan as Covid-19 Cases Grow Rapidly. Library of Congress. 2020 Jun 25. URL: https://www.loc.gov/law/foreign-news/article/ pakistan-smart-lockdown-imposed-across-cities-of-pakistan-as-covid-19-cases-grow-rapidly/ [accessed 2020-09-29]

21. Pakistan: Border closures extended for two weeks on April 13 /update 17. Garda World. 2020 Apr 14. URL: https://www. garda.com/crisis24/news-alerts/332031/pakistan-border-closures-extended-for-two-weeks-on-april-13-update-17 [accessed 2020-10-08]

22. COVID-19: Number of quarantined people in Taftan reaches 4,000. The Express Tribune. 2020 Mar 11. URL: https:/ /tribune.com.pk/story/2173842/covid-19-number-quarantined-people-taftan-reaches-4000 [accessed 2020-09-30]

23. Ellis-Petersen H, Baloch SM. Pakistan coronavirus camp: 'No facilities, no humanity'. The Guardian. 2020 Mar 19. URL: https://www.theguardian.com/world/2020/mar/19/pakistan-coronavirus-camp-no-facilities-no-humanity [accessed 2020-10-03]

24. 'Pakistan's preparation, response to Covid-19 one of the best worldwide'. The Express Tribune. 2020 Jul 19. URL: https:/ /tribune.com.pk/story/2255603/pakistans-preparation-response-to-covid-19-one-of-the-best-worldwide [accessed 2020-09-27]

25. Hashim A. Pakistan wins rare, fragile success against novel coronavirus. Al Jazeera. 2020 Aug 25. URL: https://www. aljazeera.com/news/2020/08/25/pakistan-wins-rare-fragile-success-against-novel-coronavirus/ [accessed 2020-09-29]

26. Khan MI. Coronavirus updates: Pakistan imposes curfew to curtail Friday prayers. BBC News. 2020 Apr 03. URL: https:/ /www.bbc.com/news/world-asia-52149688 [accessed 2020-10-01]

27. Raza Z. Curfew remains only solution to keep people confined to home. Daily Times. 2020 Mar 31. URL: https://dailytimes. com.pk/586250/curfew-remains-only-solution-to-keep-people-confined-to-home [accessed 2020-09-26]

28. Govt in limbo over banning congregation prayers in mosques amidst virus lockdown. Dawn. 2020 Mar 25. URL: https:/ /www.dawn.com/news/1543355 [accessed 2020-09-25]

29. Hassan SR. Pakistan's Sindh province bans prayer at mosques during Ramadan. Reuters. 2020 Apr 24. URL: https://www. reuters.com/article/us-health-coronavirus-ramadan-pakistan/ pakistans-sindh-province-bans-prayer-at-mosques-during-ramadan-idUSKCN226166 [accessed 2020-09-30]

30. Asghar I. Rawalpindi administration seals three neighbourhoods amid COVID-19 outbreak fears. The Express Tribune. 2020 Mar 28. URL: https://tribune.com.pk/story/2186327/

rawalpindi-administration-seals-three-neighbourhoods-amid-covid-19-outbreak-fears [accessed 2020-10-01]

31. Contact Tracing. Centers for Disease Control and Prevention. URL: https://www.cdc.gov/coronavirus/2019-ncov/ daily-life-coping/contact-tracing.html [accessed 2020-10-02]

32. Dagia N. Inside Pakistan's COVID-19 Contact Tracing. The Diplomat. 2020 Jul 01. URL: https://thediplomat.com/2020/ 07/inside-pakistans-covid-19-contact-tracing/ [accessed 2020-09-29]

33. FELTP: The Frontline of Defense Against COVID-19 in Pakistan. Centers for Disease Control and Prevention. 2020 Jul 21. URL: https://www.cdc.gov/globalhealth/healthprotection/fetp-40th-anniversary/stories/pakistan-feltp-covid.html [accessed 2020-10-01]

34. NCOC to re-close public service sectors if SOPs compliance goes neglected. Associated Press of Pakistan. 2020. URL: https://www.app.com.pk/national/ncoc-to-re-close-public-service-sectors-if-sops-compliance-goes-neglected/ [accessed 2020-10-01]

35. Corona Virus Public Awareness Campaign. Reliefweb. 2020 Mar 22. URL: https://reliefweb.int/report/pakistan/ corona-virus-public-awareness-campaign [accessed 2020-09-26]

36. COVID-19 in Pakistan: WHO fighting tirelessly against the odds. World Health Organization. 2020 Nov 09. URL: https:/ /www.who.int/news-room/feature-stories/detail/covid-19-in-pakistan-who-fighting-tirelessly-against-the-odds [accessed 2020-12-31]

37. Zong 4G and UNICEF Pakistan Partner to Create Awareness around COVID-19. UNICEF. 2020 Apr 28. URL: https:/ /www.unicef.org/pakistan/press-releases/zong-4g-and-unicef-pakistan-partner-create-awareness-around-covid-19 [accessed 2020-10-03]

38. Survey Report: Impact of COVID-19 on SMEs. Small and Medium Enterprises Development Authority. 2020 Apr. URL: https://smeda.org/phocadownload/Research Publications/ SMEDA\%20Survey\%20Report\%20-\%20COVID-19\%20Impact\%20on\%20SMEs\%20reduce.pdf [accessed 2021-05-04]

39. Ehsaas Cash programme helped country respond to crisis successfully: Sania Nishtar. The Nation. 2020 Oct 09. URL: https://nation.com.pk/09-Oct-2020/ehsaas-cash-programme-helped-country-respond-to-crisis-successfully-sania-nishtar [accessed 2020-10-10]

40. PM Imran announces incentives for construction industry. The Nation. 2020 Apr 04. URL: https://nation.com.pk/04-Apr-2020/ pm-imran-announces-incentives-for-construction-industry [accessed 2020-09-26]

41. Chaudhry A. Pakistan's guidelines on home isolation against WHO, Chinese recommendations. Dawn. 2020 Apr 10. URL: https://www.dawn.com/news/1547879 [accessed 2020-09-25]

42. International Association of Science Parks and Areas of Innovation. URL: https://www.iasp.ws/covid19/nrtc-ventilators [accessed 2020-09-25] 
43. PM inaugurates NRTC production facility: PMO. The Nation. 2020 Jul 06. URL: https://nation.com.pk/06-Jul-2020/ pm-inaugurates-nrtc-production-facility-pmo [accessed 2020-09-24]

44. Pakistan Cases Details. Government of Pakistan. URL: https://covid.gov.pk/stats/pakistan [accessed 2020-10-01]

45. HDF distributes ration among 350 families in rural parts of the district - Daily Parliament Times. Human Development Foundation Pakistan. 2020 May 22. URL: https://hdfpk.com/category/covid-19/ [accessed 2020-10-02]

46. Al-Khidmat Foundation plays leading role in fight against Covid-19. The News. URL: https://www.thenews.com.pk/print/ 688169-al-khidmat-foundation-plays-leading-role-in-fight-against-covid-19 [accessed 2020-10-03]

47. Riaz R. Pakistani charity arranges free plasma for COVID-19 patients. Arab News. 2020 Jun 11. URL: https://www. arabnews.pk/node/1688336/pakistan [accessed 2020-10-02]

48. Tag: Corona Recovered Warriors - Pakistanis Turn To 'Corona Warriors' Facebook Group For Plasma Donations. When Where How. 2020 Jun 30. URL: https://whenwherehow.pk/tag/corona-recovered-warriors/ [accessed 2020-10-01]

49. Ahmed A. These 'Corona Warriors' Are Countering Plasma Black Market by Connecting People with Volunteer Donors. ProPakistani. URL: https://propakistani.pk/2020/07/07/

these-corona-warriors-are-countering-plasma-black-market-by-connecting-people-with-volunteer-donors/ [accessed 2020-09-27]

50. Jamal S. Covid-19: Pakistani doctors get approval for plasma therapy clinical trial. Gulf News. 2020 Apr 15. URL: https:/ /gulfnews.com/world/asia/pakistan/covid-19-pakistani-doctors-get-approval-for-plasma-therapy-clinical-trial-1.70988056 [accessed 2020-10-02]

51. Latif A. Pakistan: COVID-19 patient recovers with plasma therapy. Anadolu Agency. 2020 May 09. URL: https://www. aa.com.tr/en/asia-pacific/pakistan-covid-19-patient-recovers-with-plasma-therapy/1835196 [accessed 2020-09-30]

52. Ebrahim ZT. In the fight against Covid-19, these bright, young Pakistanis are coming together and improvising. Prism. 2020 Apr 07. URL: https://www.dawn.com/news/1543349 [accessed 2020-09-29]

53. COVID-19: students assist with response. The Aga Khan University. 2020 Mar 20. URL: https://www.aku.edu/news/Pages/ News Details.aspx?nid=NEWS-002113 [accessed 2020-10-01]

54. First Response Initiative of Pakistan. URL: https://www.frip.org.pk/ [accessed 2020-09-28]

55. Ahmad Z. Pakistani volunteers 3D-print ventilators, join war against COVID-19. The Express Tribune. 2020 Mar 23. URL: https://tribune.com.pk/story/2181993/pakistani-volunteers-3d-print-ventilators-join-war-covid-19 [accessed 2020-09-25]

56. Sandhu R. Pakistan may mass produce ventilators through 3D printing. News Lens Pakistan. 2020 Mar 23. URL: https:/ /www.newslens.pk/pakistan-may-mass-produce-ventilators-3d-printing/ [accessed 2020-10-03]

57. Ejaz R. Salman Khan suggests Kwick Doctor for better and affordable health care. Disrupt Magazine. URL: https://disruptmag. pk/salman-khan-suggests-kwick-doctor-for-better-and-affordable-health-care/ [accessed 2020-09-25]

58. Wang P, Nair MS, Liu L, Iketani S, Luo Y, Guo Y, et al. Increased Resistance of SARS-CoV-2 Variants B.1.351 and B.1.1.7 to Antibody Neutralization. bioRxiv. Preprint posted online January 26, 2021 [FREE Full text] [doi: 10.1101/2021.01.25.428137] [Medline: 33532778]

\section{Abbreviations \\ PPE: personal protective equipment \\ SOP: standard operating procedure \\ WHO: World Health Organization}

Edited by DR Saadeh; submitted 05.03.21; peer-reviewed by M Faheem; comments to author 19.03.21; revised version received
08.04.21; accepted 09.04.21; published 19.05.21
Please cite as:
Akhtar H, Afridi M, Akhtar S, Ahmad H, Ali S, Khalid S, Awan SM, Jahangiri S, Khader YS
Pakistan's Response to COVID-19: Overcoming National and International Hypes to Fight the Pandemic
JMIR Public Health Surveill 2021;7(5):e28517
URL: $\underline{\text { https://publichealth.jmir.org/2021/5/e28517 }}$
doi: $10.2196 / 28517$
PMID: $\underline{3877048}$

(CHashaam Akhtar, Maham Afridi, Samar Akhtar, Hamaad Ahmad, Sabahat Ali, Sundas Khalid, Sajid Mahmood Awan, Shahzaib Jahangiri, Yousef Saleh Khader. Originally published in JMIR Public Health and Surveillance (https://publichealth.jmir.org), 19.05.2021. This is an open-access article distributed under the terms of the Creative Commons Attribution License (https://creativecommons.org/licenses/by/4.0/), which permits unrestricted use, distribution, and reproduction in any medium, provided the original work, first published in JMIR Public Health and Surveillance, is properly cited. The complete bibliographic 
information, a link to the original publication on https://publichealth.jmir.org, as well as this copyright and license information must be included. 